\title{
Large spatial variation in accumulation rate in Jutulstraumen ice stream, Dronning Maud Land, Antarctica
}

\author{
KJetil Melvold, ${ }^{1}$ Jon Ove Hagen, ${ }^{1}$ Jean Francis Pinglot, ${ }^{2}$ Niels Gundestrup ${ }^{3}$ \\ ${ }^{1}$ Department of Physical Geography, University of Oslo, Box 1042, Blindern, $\mathcal{N}-0316$ Oslo, Norway \\ ${ }^{2}$ Laboratoire de Glaciologie et Géophysique de l'Environnement du CNRS, \\ and Université foseph Fourier, 38402 Saint-Martin-d'Hères Cedex, France \\ ${ }^{3}$ Geophysical Department, University of Copenhagen, Juliane Maries Vej 30, DK-2100 Copenhagen, Denmark
}

\begin{abstract}
A mass-balance programme was initiated on Jutulstraumen ice stream, western Dronning Maud Land,Antarctica, during the austral summer 1992-93. As a part of the mass-balance programme, accumulation rate was measured along the centre line of Jutulstraumen from the shelf edge up to the plateau at about $2500 \mathrm{~m}$ a.s.l.

Accumulation distribution obtained from seven shallow firn cores and 48 stake readings is presented. The overall net accumulation trend displays a decreasing accumulation with increasing elevation and distance to coast, but on both the mesoscale and microscale there are significant variations. This is due to complex patterns of precipitation controlled by orography and redistribution by katabatic winds. The local accumulation distribution (few km scale) was found to be dependent on downslope surface gradient (aspect north, northwest), and variations up to $100 \%$ were found over distances of less than $3 \mathrm{~km}$. The large variation in accumulation is important when selecting new core sites and for interpretation of temporal and spatial variations in accumulation derived from firn cores.
\end{abstract}

\section{INTRODUCTION}

As part of the Norwegian Antarctic Research Expeditions (NARE), a mass-balance and glacier dynamics research project has been started on Jutulstraumen ice stream, western Dronning Maud Land, Antarctica. The project was initiated during the austral summer 1992-93 and has been continued during the 1993-94 and 1996-97 seasons. In this paper we discuss the results of surface mass-balance measurements obtained from stakes and shallow firn cores, concentrating on spatial variation in the accumulation. The temporal variation of accumulation and the climatic implications will be discussed in another paper.

\section{Jutulstraumen ice stream}

Jutulstraumen ice stream is located in Dronning Maud Land, near the Greenwich (zero) meridian (Fig. 1). Jutulstraumen with its ice-shelf area Fimbulisen is fed by parts of Amundsenisen and Wegnerisen, and the total drainage system has an area of $124000 \mathrm{~km}^{2}$ (N. F. McIntyre, quoted by Swithinbank, 1988). This makes it the largest ice stream in western Dronning Maud Land $\left(15^{\circ} \mathrm{W}-20^{\circ} \mathrm{E}\right)$. The inland ice is dammed by the mountain range Kirwanveggen and Neumayerskarvet to the west and H. U. Sverdrupfjella, Gjelsvikfjella and Münlig-Hofmannfjella to the east, and ice is channelled through Jutulstraumen. The mainstream follows a major deep valley believed to be of structural origin (Decleir and Van Autenboer, 1982). A more detailed description of the physiography of the area is given by Swithinbank (1959, 1988) and Gjessing (1972). Høydal (1996) used new surface-velocity measurements obtained during NARE 1992-93 and gravity profiles across Jutulstraumen and Viddalen presented by Decleir and Van Autenboer (1982) to calculate an ice discharge of $13.1 \mathrm{~km}^{3} \mathrm{a}^{-1}$ at latitude $72^{\circ} 15^{\prime} \mathrm{S}$ (about $40-50 \mathrm{~km}$ south of the grounding line at an elevation of $1000 \mathrm{~m}$ a.s.l.).

\section{METHODS}

The approach followed in this work is based on traditional methods of obtaining data on surface accumulation in Antarctica: direct stake readings and shallow-core analysis.

\section{Stake measurements}

During the first field season (1992-93), 44 accumulation and velocity marker stakes were set up in the elevation range 710-1200 ma.s.l. (Fig. 1). Thirty-six of these stakes were placed between Nashornkalvane and Jutulrøra, giving a $50 \mathrm{~km}$ long line across Jutulstraumen (profile 1), and six stakes were planted between Nashornkalvane and Istind (profile 2). The stake spacing was about $4 \mathrm{~km}$, except for three rectangular strain nets with nine stakes $(3 \times 3)$ in each with a spacing of about $1 \mathrm{~km}$. Stakes were also put out at drill sites B and D in 1992-93 and E, F, G and H in 1993 94. The height of all stakes not covered by snow was measured during the 1993-94 season (19 of 42 stakes) and the 1996-97 season (4 of 48 stakes). The snow accumulation from the stakes was converted to water equivalents by multiplying by snow-density values taken from a mean densification curve. The curve was obtained from a compilation of density profiles from five pits for depths of $0-1.5 \mathrm{~m}$ and from cores at depths greater then $1.5 \mathrm{~m}$ (Melvold and others, 1996; 


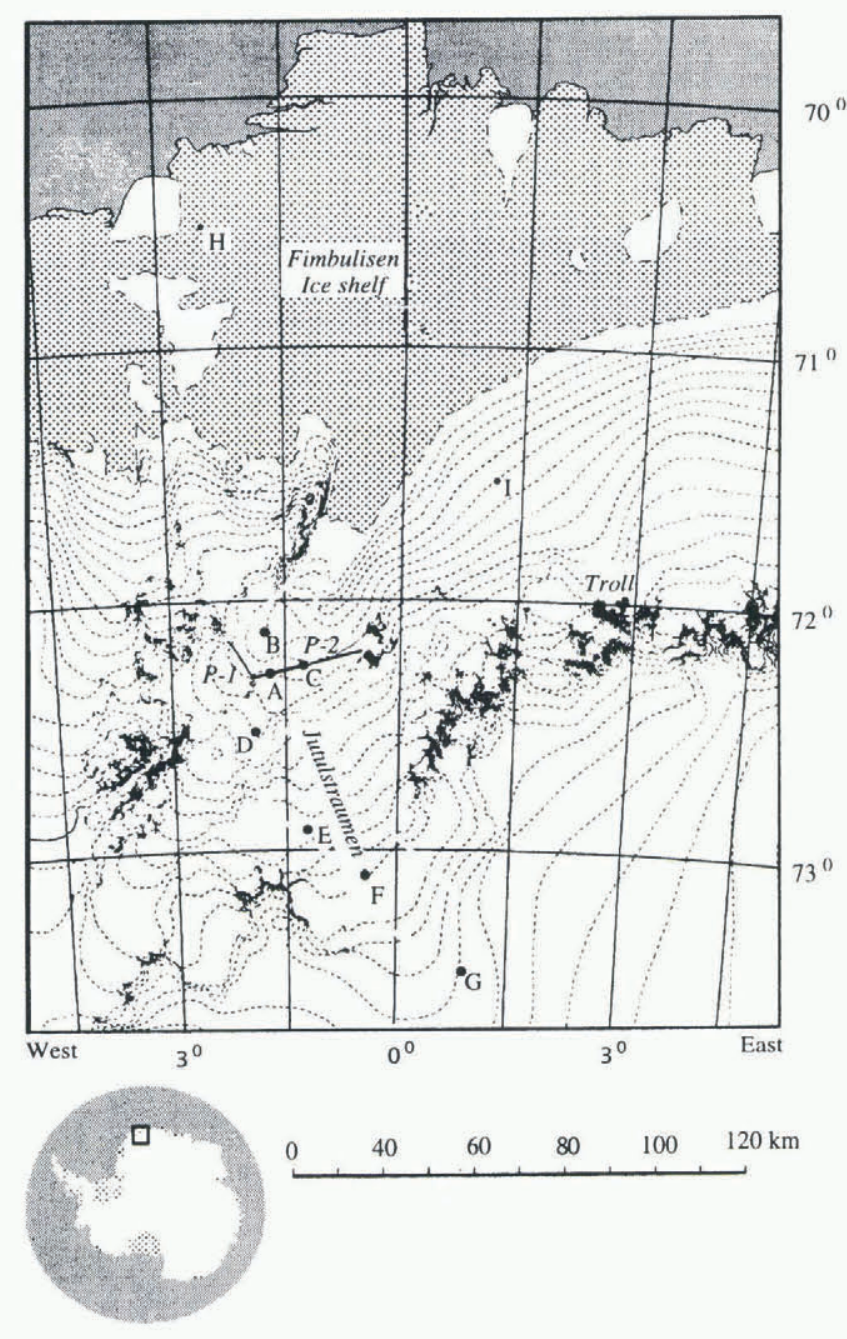

Fig. 1. Jutulstraumen and Fimbulisen, showing the stake profiles $(P-1=$ profile $1 ; P-2=$ profile 2$)$ and shallow-core sites.

Hagen and Melvold, 1997). For the accumulation calculation it is assumed that the bottom of each stake is firmly fixed.

In conjunction with the stake readings made in 1993 , stake positions along profiles 1 and 2 were measured using phase-tracking kinematic global positioning system (GPS) techniques (see Eiken and others, 1997, for a full description of the technique used). Along profile 1 (Fig. 1) and in the three strain nets the same techniques were used for surface levelling. The measurements were carried out with an epoch time of 5 seconds, giving a $30 \mathrm{~m}$ spacing between the measured surface elevation points. Static GPS techniques were used to position the core locations and the stakes. The measurements were always carried out with a reference receiver on fixed point.

\section{Shallow cores}

During the two field seasons, nine shallow firn cores with depths of 13-32 $\mathrm{m}$ were drilled at different sites in the drainage area. The site elevations ranged from the ice shelf up to about 2400 ma.s.l. (Fig. 1). A Polar Ice Coring Office (PICO) lightweight auger with a diameter of $7.69 \mathrm{~cm}$ was used. Density profiles were determined in the field by measuring the length, diameter and weight of each core section
$(10-40 \mathrm{~cm})$. The density of the uppermost metre was measured in a snow pit, as the core broke apart due to the low density. All firn-core sections were packed in plastic tubes and returned frozen to Norway. Core length, distance from coast and position of each core are listed in Table 1.

Table 1. Positions of firn cores

\begin{tabular}{|c|c|c|c|c|}
\hline Core site & Lat./long. & Core length & $\begin{array}{l}\text { Distance from } \\
\text { coast }\end{array}$ & Elevation \\
\hline & & $\mathrm{m}$ & $\mathrm{km}$ & m a.s.l. \\
\hline A & $\begin{array}{l}72^{\circ} 17^{\prime} 04^{\prime \prime} \mathrm{S} \\
01^{\circ} 42^{\prime} 21^{\prime \prime} \mathrm{W}\end{array}$ & 22.07 & 292 & 905 \\
\hline B & $\begin{array}{l}72^{\circ} 07^{\prime} 50^{\prime \prime} \mathrm{S} \\
01^{\circ} 45^{\prime} 37^{\prime \prime} \mathrm{W}\end{array}$ & 20.41 & 277 & 710 \\
\hline C & $\begin{array}{l}72^{\circ} 15^{\prime} 39^{\prime \prime} \mathrm{S} \\
01^{\circ} 15^{\prime} 34^{\prime \prime} \mathrm{W}\end{array}$ & 13.8 & 282 & 882 \\
\hline $\mathrm{D}$ & $\begin{array}{l}72^{\circ} 30^{\prime} 55^{\prime \prime} \mathrm{S} \\
01^{\circ} 54^{\prime} 53^{\prime \prime} \mathrm{W}\end{array}$ & 16.2 & 317 & 1183 \\
\hline $\mathrm{E}$ & $\begin{array}{l}72^{\circ} 58^{\prime} 40^{\prime \prime} \mathrm{S} \\
01^{\circ} 07^{\prime} 39^{\prime \prime} \mathrm{W}\end{array}$ & 17.31 & 362 & 1817 \\
\hline F & $\begin{array}{l}73^{\circ} 05^{\prime} 49^{\prime \prime} \mathrm{S} \\
00^{\circ} 27^{\prime} 30^{\prime \prime} \mathrm{W}\end{array}$ & 18.33 & 379 & 1974 \\
\hline $\mathrm{H}$ & $\begin{array}{l}70^{\circ} 30^{\prime} 00^{\prime \prime} \mathrm{S} \\
02^{\circ} 27^{\prime} 48^{\prime \prime} \mathrm{W}\end{array}$ & 31.86 & 95 & 52 \\
\hline I & $\begin{array}{l}71^{\circ} 30^{\prime} 51^{\prime \prime} \mathrm{S} \\
01^{\circ} 10^{\prime} 51^{\prime \prime} \mathrm{W}\end{array}$ & 13.6 & 265 & 600 \\
\hline
\end{tabular}

\section{Laboratory}

The firn cores were cut and prepared in a cold laboratory for measurements of stable oxygen isotopes, total $\beta$ radioactivity and gamma spectrometry. For the radio-isotope measurements, samples with a mass of about $200 \mathrm{~g}$ (length 10 $20 \mathrm{~cm}$ ) were cut contiguously from the cores to ensure an adequate temporal resolution. These samples, a total of 900, were melted, acidified and pumped through ion-exchange filters (Delmas and Pourchet, 1977), after which total $\beta$ radioactivity was measured by methods described by Pinglot and Pourchet (1979). Assemblies of ion-exchange filters were made for high-resolution gamma spectrometry (about five gamma-ray samples per firn core), to detect the ${ }^{137} \mathrm{Cs}$ fall-out (the most abundant artificial long-lived radionuclide) (Pinglot and Pourchet, 1981).

For the oxygen-isotopic ratios $\left(\delta^{18} \mathrm{O}\right)$, samples were cut contiguously along the length of the cores. The sample length ranged from about $4 \mathrm{~cm}$ for the coastal sites and gradually decreased to $1.5 \mathrm{~cm}$ for core $\mathrm{F}$ on the plateau, in order to ensure that about 15 samples per annual layer could be obtained for detection of the annual signal (Peel and Clausen, 1982). Accumulation records from previous expeditions were used to select appropriate sample thickness (Schytt, 1958; Lunde, 1961; Orheim and others, 1986; Isaksson and Karlén, 1994).

\section{RESULTS}

\section{Stake measurements}

\section{Accumulation}

The accumulation pattern found from stake measurements shows a large spatial variability along Jutulstraumen. The 


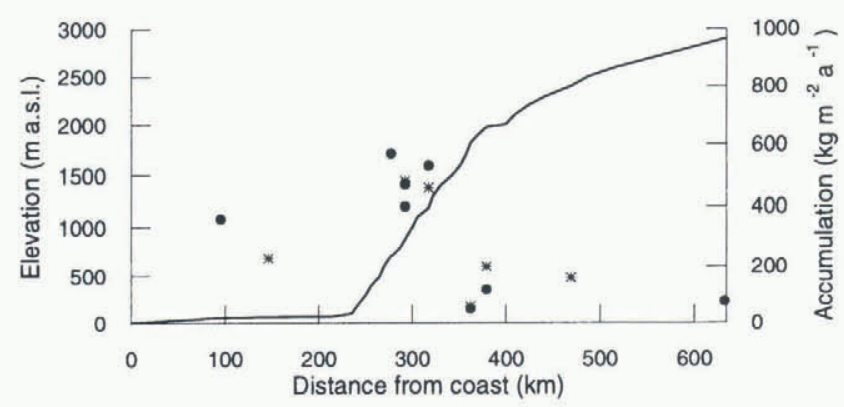

Fig. 2. Surface elevation and accumulation along futulstraumen traverse from the ice-shelf edge to the plateau. The elevations are taken from topographical maps and GPS measurements at the core locations. Mean accumulation obtained from the cores and the stakes is shown by solid circles and solid stars, respectively. Data on the accumulation at $620 \mathrm{~km}$ are from Isaksson and others (1996).

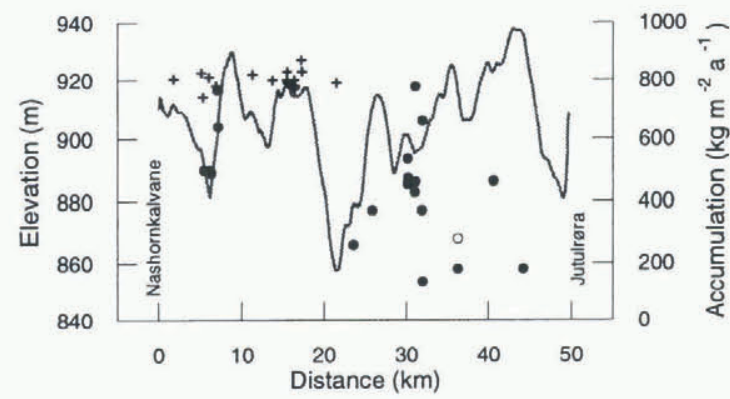

Fig. 3. Accumulation rate measured at stakes shown by solid circles between 1993 and 1994 and surface elevation along the $50 \mathrm{~km}$ long profile 1. Solid crosses show the minimum accumulation for stakes covered by snow between 1993 and 1994, and open circle the mean value between 1993 and 1997. The locations of Nashornkalvane and Jutulrora are indicated. Note the large exertion of the elevation. accumulation ranges from $230 \mathrm{~kg} \mathrm{~m}^{-2} \mathrm{a}^{-1}$ at the ice shelf to a mean of $460 \mathrm{~kg} \mathrm{~m}^{-2} \mathrm{a}^{-1}$ at $900-1000 \mathrm{~m}$ elevation, to $160 \mathrm{~kg} \mathrm{~m}^{-2} \mathrm{a}^{-1}$ at $2400 \mathrm{~m}$ elevation (Fig. 2). For a 1 year period (1993-94) along the $50 \mathrm{~km}$ long profile (profile 1) crossing Jutulstraumen at about $900 \mathrm{~m}$ a.s.l. (Fig. 3) the accumulation ranged from 140 to more than $780 \mathrm{~kg}$ $\mathrm{m}^{-2} \mathrm{a}^{-1}$. The mean value was $460 \mathrm{~kg} \mathrm{~m}^{-2} \mathrm{a}^{-1}$ and its standard deviation was $190 \mathrm{~kg} \mathrm{~m}^{-2} \mathrm{a}^{-1}$. Figure 3 shows the measured accumulation at 19 of the 36 measured stakes, and the estimated minimum accumulation at the 17 stakes which were covered by snow during the 1994 measurements. Minimum accumulation was estimated by setting the snow depth equal to total stake height above the snow surface in 1993. The accumulation rate across Viddalen (profile 2) is greater than $780 \mathrm{~kg} \mathrm{~m}^{-2} \mathrm{a}^{-1}$ (only one of six stakes was not covered by snow) except in the area close to the Nashornkalvane nunatak (a stake was situated $700 \mathrm{~m}$ north of the nunatak) where an accumulation rate of only $180 \mathrm{~kg} \mathrm{~m}^{-2} \mathrm{a}^{-1}$ was found. Large areal variability in accumulation rate was also found within the three stake strain networks situated in profile 1. This is illustrated in Figure 4 which shows the spatial distribution of accumulation for a stake network ( $3 \times 3$ stakes) situated $15 \mathrm{~km}$ west of Jutulrøra nunatak. The distribution was obtained by kriging interpolation of the measured accumulation at the stakes (Fig. 4). The variation in net accumulation rate was systematic and reached $100 \%\left(500 \mathrm{~kg} \mathrm{~m}^{-2} \mathrm{a}^{-1}\right)$ in less then $3 \mathrm{~km}$ between 1992-93 and 1993-94.

\section{Surface elevation}

Surface elevation profiles across Jutulstraumen obtained from the kinematic GPS levelling are shown in Figure 3. They show small-scale undulations in the surface topography, with shallow valleys and low ridges. A maximum height difference of $80 \mathrm{~m}$ between the valley bottom and corresponding ridges was found in the central part of the

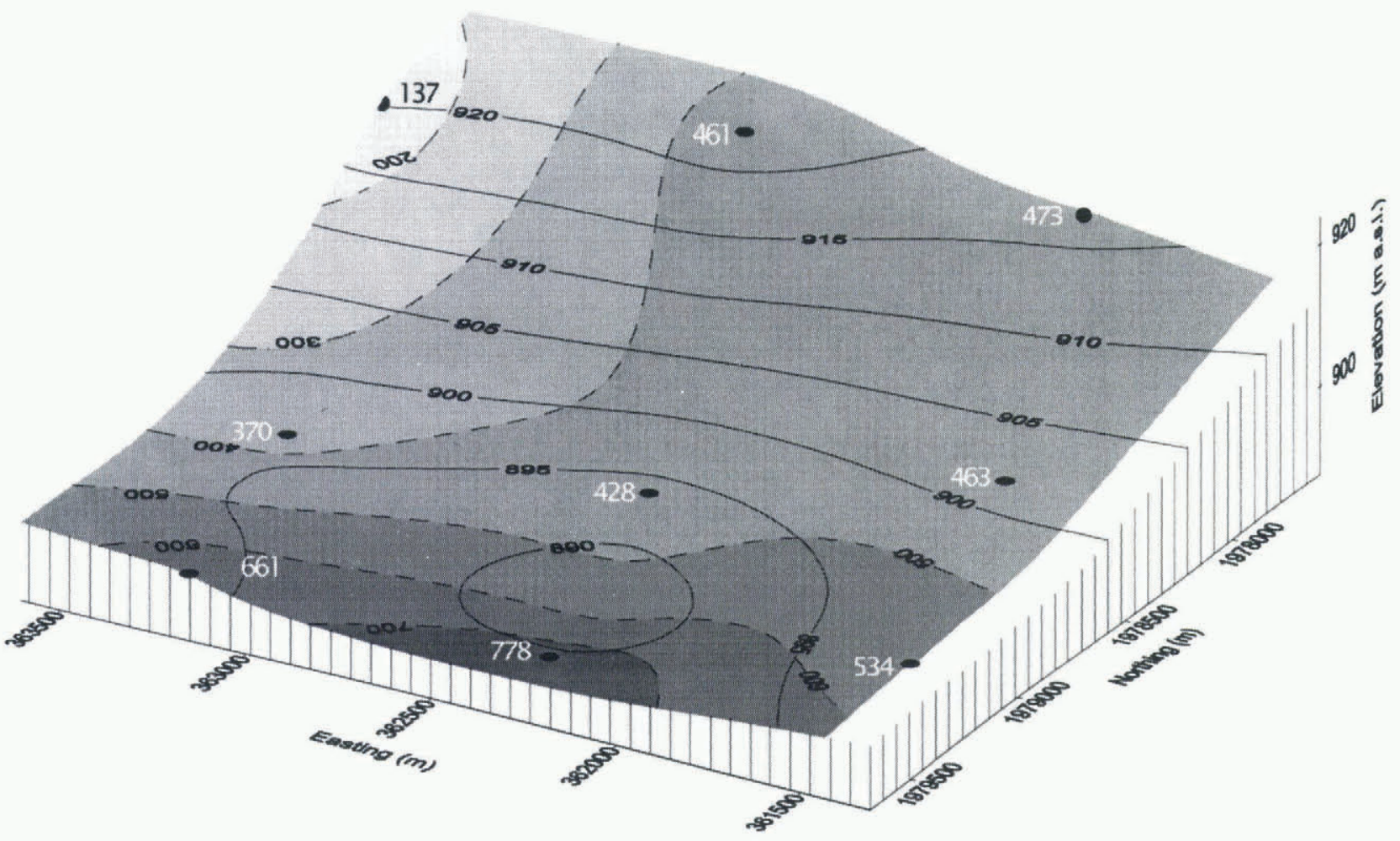

Fig. 4. Spatial distribution of accumulation shown by field contours, and measured accumulation at stakes shown by crosses in $\mathrm{kg} \mathrm{m}^{-2} a^{-1}$ for strain net 3. The accumulation is draped over the DEM of the plots, and contour interval is $5 \mathrm{~m}$. 


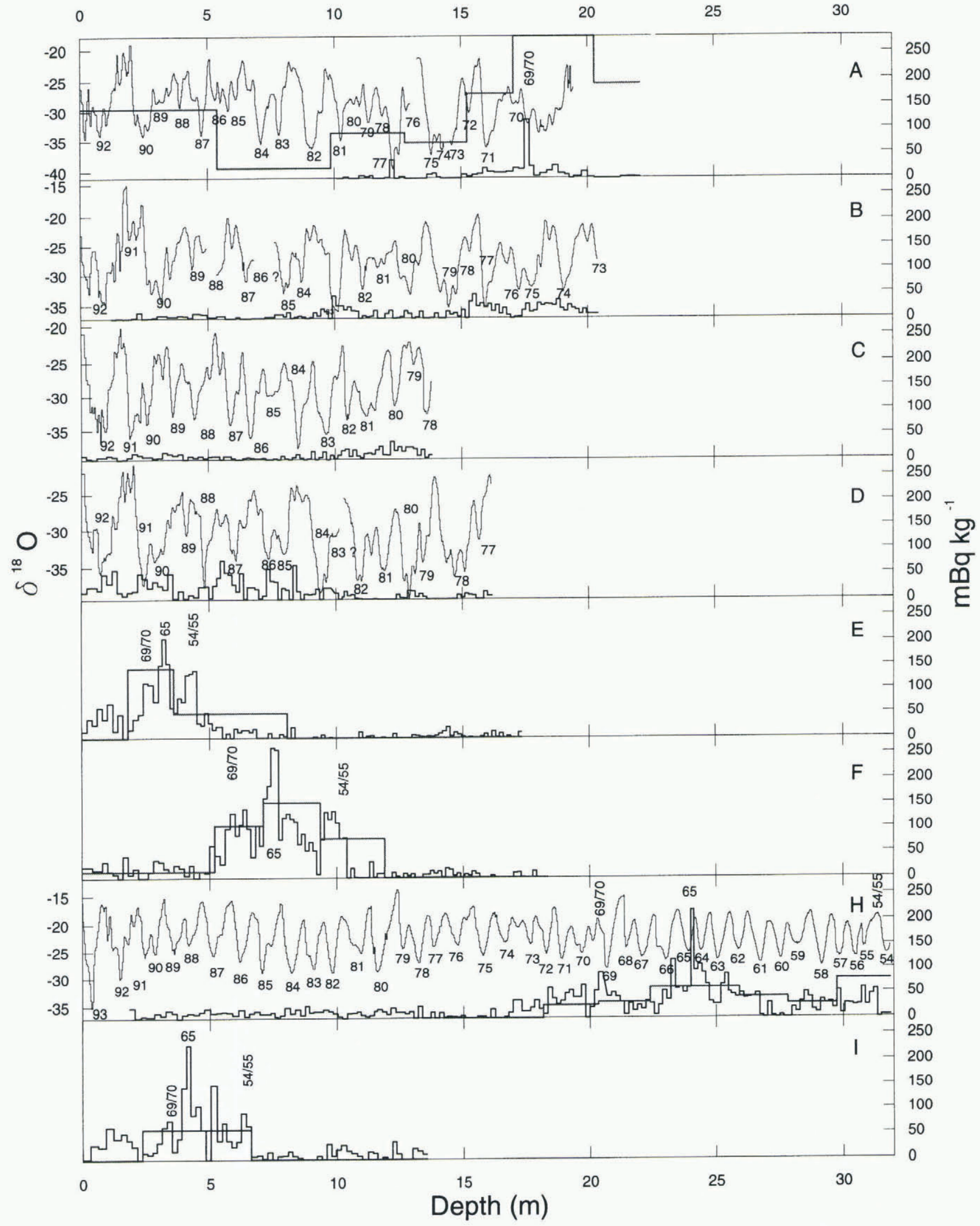

Fig. 5. Specific total $\beta$ radioactivity (heavy line), gamma ${ }^{137} \mathrm{Cs}$ (dotted line) activity for cores $A-F, H$ and $I$, and oxygen $\delta^{18} O$ profiles at sites $A-D$ and $H$. Adapted time-scales are shown. The dating is tentative on cores $A-D$. The scale for ${ }^{137} C$ s activity is only $1 / 10$ of the $\mathrm{mBq} \mathrm{kg}{ }^{-1}$ shown in the figure.

cross-profile. A digital elevation model (DEM) of the surface in the stake strain network situated $15 \mathrm{~km}$ west of Jutulrøra nunatak was interpolated (Fig. 4). The DEM was derived from over 200 measurements of surface elevation retrieved from the phase-tracking kinematic GPS survey in
1993. Generally, the maximum surface slope (aspect north) follows the flow direction from south to north. Over the whole area, surface slope varies from less then zero in a concavity in the north-central section to about $2.0^{\circ}$ in the southeastern section. 
Table 2. Annual accumulation rates in $\mathrm{kg} \mathrm{m}^{-2} a^{-1}$ for core sites $A-D$ and $H$, based on the $\delta^{18} O$ stratigraphy. Mean accumulation over the 1993-95 period in $\mathrm{kg} \mathrm{m}^{-2} a^{-1}$ for firn cores $A, E, F, H$ and I, based on $\beta$ radioactivity

\begin{tabular}{|c|c|c|c|c|c|c|c|c|c|}
\hline Year & Number of years & $A$ & B & $C$ & $D$ & $E$ & $F$ & $H$ & $I$ \\
\hline 1993 & & & & & & & & 310 & \\
\hline 1992 & & 590 & 550 & 590 & 750 & & & 620 & \\
\hline 1991 & & 290 & 500 & 390 & 610 & & & 270 & \\
\hline 1990 & & 350 & 600 & 480 & 440 & & & 240 & \\
\hline 1989 & & 380 & 540 & 460 & & & & 390 & \\
\hline 1988 & & 280 & 520 & 400 & 440 & & & 310 & \\
\hline 1987 & & 420 & 470 & 450 & 690 & & & 610 & \\
\hline 1986 & & 330 & 390 & 360 & 520 & & & 410 & \\
\hline 1985 & & 330 & 390 & 360 & 410 & & & 620 & \\
\hline 1984 & & 550 & 410 & 480 & 640 & & & 520 & \\
\hline 1983 & & 360 & 730 & 540 & 490 & & & 450 & \\
\hline 1982 & & 680 & 530 & 610 & 600 & & & 360 & \\
\hline 1981 & & 620 & 460 & 540 & 490 & & & 700 & \\
\hline 1980 & & 310 & 730 & 520 & 530 & & & 610 & \\
\hline 1979 & & 320 & 880 & 600 & & & & 250 & \\
\hline 1978 & & 260 & 410 & 330 & 560 & & & 430 & \\
\hline 1977 & & 310 & 430 & & 360 & & & 430 & \\
\hline 1976 & & 310 & 690 & & 360 & & & 690 & \\
\hline 1975 & & 480 & 410 & & & & & 540 & \\
\hline 1974 & & 330 & 830 & & & & & 420 & \\
\hline 1973 & & 240 & 850 & & & & & 600 & \\
\hline 1972 & & 400 & & & & & & 470 & \\
\hline 1971 & & 450 & & & & & & 430 & \\
\hline 1970 & & 570 & & & & & & 660 & \\
\hline 1969 & & 350 & & & & & & 690 & \\
\hline 1968 & & & & & & & & 280 & \\
\hline 1967 & & & & & & & & 510 & \\
\hline 1966 & & & & & & & & 610 & \\
\hline 1965 & & & & & & & & 470 & \\
\hline Mean & & 400 & 570 & 470 & 530 & & & 480 & \\
\hline $1965-93 / 94$ & 29 & $410^{1}$ & $>500$ & $>330$ & $>380$ & 50 & 120 & 480 & 60 \\
\hline $1993-94^{2}$ & 1 & $500-760$ & & 280 & 460 & & & & \\
\hline $1993-97^{2}$ & 3 & $>420$ & & 450 & & 60 & 200 & & \\
\hline
\end{tabular}

\footnotetext{
${ }^{1}$ Mean between 1993 and $1969 .{ }^{2}$ Based on stake measurements.
}

\section{Firn-core stratigraphy}

\section{Isotope profiles}

Core $\mathrm{H}$ from the ice shelf close to Norway station (Fig. 1) is taken as the reference for the radioactivity and stable oxygen-isotope profiles, as its high accumulation rate of $480 \mathrm{~kg}$ $\mathrm{m}^{-2} \mathrm{a}^{-1}$ results in the best vertical resolution. Figure 5 illustrates the $\beta$ radioactivity profile along with the ${ }^{137} \mathrm{Cs}$ and $\delta^{18} \mathrm{O}$ for this core. The $\beta$ radioactivity profile exhibits one clear maximum at a depth of $24.12-24.28 \mathrm{~m}$, and one less pronounced peak at a depth of $20.67-20.85 \mathrm{~m}$. We assume that these two peaks correspond to January 1965 and January 1969 (e.g. Picciotto and others, 1971; Clausen and others, 1979; Aristarain and others, 1987). The $\delta^{18} \mathrm{O}$ stratigraphy shows well-developed seasonal variation (characterised by high $\delta^{18} \mathrm{O}$ content in summer snow layers and low $\delta^{18} \mathrm{O}$ content in winter snow layers), but the amplitudes clearly reduce with increasing depth. The annual $\delta^{18} \mathrm{O}$ cycles, however, are still preserved, allowing year-to-year dating. The radioactivity peaks of 1965 and 1969 coincide with 1965 and 1969 identified by counting the delta cycles. The first increase in $\beta$ radioactivity occurs near the bottom of the core at a depth of $31 \mathrm{~m}$. This increase which is assumed to be the 1954-55 summer coincides with January 1955 identified by counting annual variations in $\delta^{18} \mathrm{O}$. The 1969 and 1965 levels are confirmed by gamma spectrometry which gives a ${ }^{137} \mathrm{Cs}$ fall-out of $30 \mathrm{~Bq} \mathrm{~m}^{-2}$ (at time of measurement).
We have no clear interpretation for the occurrence of ${ }^{137} \mathrm{Cs}$ below $30 \mathrm{~m}$ as it is correlated with low values of total beta.

Figure $5 \mathrm{e}, \mathrm{f}$ and $\mathrm{i}$ illustrate the $\beta$ radioactivity profile, along with the ${ }^{137} \mathrm{Cs}$ for each of the samples in cores $\mathrm{E}, \mathrm{F}$ and I. Note the similarity between the individual cores and the similarity with the profile of core $\mathrm{H}$. Note also the similarity in mean values for the $\beta$ radioactivity at the 1969 and 1965 levels in the different cores. In these radioactivity profiles the shift in activity from a low background value of $0-40 \mathrm{mBq} \mathrm{kg}^{-1}$ to approximately $100-150 \mathrm{mBq} \mathrm{kg}^{-1}$ is assumed to be the 1954-55 summer level. This interpretation is similar to results from elsewhere in Antarctica (e.g. Picciotto and others, 1971; Clausen and others, 1979; Petit and others, 1982; Aristarain and others, 1987). The shift is weaker than found in records from the Antarctic interior (e.g. Petit and others, 1982) but similar to what is recognised in records from coastal stations in western Dronning Maud Land (Isaksson and Karlén, 1994) and the Antarctic Peninsula (Aristarain and others, 1987). Cores E, F and I lack a well-defined seasonality in the concentrations of $\delta^{18} \mathrm{O}$. The period 1964-94, represented by $4.45,7.55$ and $4.15 \mathrm{~m}$ of firn above the reference horizon of 1964-65, contains not more than $6(\mathrm{E}), 16(\mathrm{~F})$ and 7 (I) more-or-less clear delta cycles, while a complete, undisturbed layering should contain 29 annual delta cycles. This means that the observed delta cycles cannot be interpreted as representative of annual accumulation. 
Figure $5 \mathrm{a}-\mathrm{d}$ illustrate the $\beta$ radioactivity profile along with the ${ }^{137} \mathrm{Cs}$ and $\delta^{18} \mathrm{O}$ for each sample in cores $\mathrm{A}-\mathrm{D}$. Note that no clear increase in $\beta$ radioactivity and ${ }^{137} \mathrm{Cs}$ occurs in cores B-D, while an increase occurs at a depth of 17.50 $17.71 \mathrm{~m}$ in core $\mathrm{A}$. We assume that the 1965 and 1969 horizons are never reached at core sites $\mathrm{B}-\mathrm{D}$ and that the increase in $\beta$ radioactivity in core $\mathrm{A}$ corresponds to the 1969 horizon. This assumption is based on the fact that the $1969 \beta$ radioactivity horizon has similar mean values in core $\mathrm{A}$ and in cores $\mathrm{E}, \mathrm{F}, \mathrm{I}$ and $\mathrm{H}$. The variations in $\delta^{18} \mathrm{O}$ at core sites $\mathrm{A}-$ $\mathrm{D}$ show a less pronounced signal than in core $\mathrm{H}$. The signal is partly cyclic, but some annual layers contain double peaks, a phenomenon also known from the Antarctic Peninsula (Peel and Clausen, 1982). In some years, the annual $\delta^{18} \mathrm{O}$ cycles are smaller than normal (e.g. 1984-85 in core D). The difference of less than $10 \%$ between summer and winter surface is common for these layers. Consequently, year-by-year dating using $\delta$ cycles is not straightforward and any interpretation must be tentative. Nevertheless, a dating is given in Figure 5, using the fact that the 1969 level is never reached in cores $\mathrm{B}-\mathrm{D}$ and just reached in core $\mathrm{A}$, as dated independently by $\beta$ radioactivity.

\section{Accumulation}

Based on the chronological information deduced from the $\beta$ radioactivity and $\delta^{18} \mathrm{O}$ the snow-accumulation increments were converted to mass using density profiles obtained from the core sites. The mean values for the period 1965-93 are calculated for cores E, F, H and A (1969-93) (Table 2). The mean annual accumulation values for cores $\mathrm{A}-\mathrm{D}$ in the period covered by each core are given in Table 2 . They show considerable interannual variability, up to $250 \%$ (Table 2). The error is assumed to be between \pm 10 and $\pm 100 \mathrm{~kg}$ $\mathrm{m}^{-2} \mathrm{a}^{-1}$, taking into consideration errors in the density determination, the depth measurements and the sampling procedures.

The spatial accumulation distribution along Jutulstraumen is shown in Figure 2, where the accumulation and elevation profiles are plotted against distance from the coast and moisture source. The elevations are based on topographical maps (Norsk Polarinstitutt map sheet No. G5G7) and elevations measured at the core sites by GPS. Accumulation values obtained from both stake measurements and cores are shown. Lunde (1961) found that the accumulation rate between 1957 and 1959 on the Jutulstraumen part of Fimbulisen was only $74 \%$ of the accumulation at Norway station (core site $\mathrm{H}$ ). Assuming that this pattern still exists, we have calculated the accumulation rate from the mean accumulation rate obtained at site $\mathrm{H}$. The values are shown in Figure 2.

\section{DISGUSSION}

The areal variability of the rate of accumulation can be split into regional and local terms (Giovinetto, 1964). The regional term in this work is the variation along Jutulstraumen from the ice shelf to the plateau. The local term has been split into two parts, along profile 1 and the areas covered by the $3 \mathrm{~km} \times 3 \mathrm{~km}$ strain network.

\section{Variation in accumulation across Jutulstraumen}

Surface elevation and surface accumulation along profile 1 are shown together in Figure 3. The profile is $50 \mathrm{~km}$ long https://doi.org/10.3189/1998AoG27-1-231-238 Published online by Cambridge University Press 236 and runs across the flow direction and mean slope of the ice stream and the mean katabatic wind direction. The accumulation variation is not related to the surface topography (e.g. both high and low accumulation occurs on local hills and hollows). The surface undulation is therefore not directly a result of different accumulation across the ice stream but is most probably a result of the underlying bedrock topography. Across Jutulstraumen the spatial variations in accumulation are considerable and cannot readily be explained by across-valley relief. However, as will be seen later, the downslope surface gradient largely controls the accumulation over small geographical areas.

Superimposed on the large variations in accumulation across Jutulstraumen is a decreasing trend in the eastern margin towards the nunatak Jutulrøra. A blue-ice area exists north of Jutulrøra, indicating even lower accumulation occurs at this site. If we use the interpretation of Van den Broeke and Bintanja (1995), this low accumulation can be explained by wind-scouring and reduced deposition of drifting snow as a result of shielding by the nunatak. The low-accumulation area situated north and west of the Jutulrøra is compatible with the effects of a southeast katabatic wind. In the area close to the Jutulrøra nunatak, the decrease in accumulation may be explained by erosion effects due to wind-channelling by the nunatak. The same effect was found on two stakes close to the northern Nashornkalvane nunatak on the western side of Jutulstraumen. The higher accumulation in the central and western part may be explained by accumulation of drifting snow. The results indicate that deposit of transported snow is an important factor in accumulation on this part of Jutulstraumen.

\section{Variation of accumulation with minor topography}

A further investigation of the areal variability of accumulation related to surface topography was conducted on a local scale for the areas covered by the strain network $(3 \mathrm{~km} \times$ $3 \mathrm{~km}$ ) (Fig. 4). The distribution of surface accumulation seems to be strongly influenced by the local topography with respect to the katabatic wind direction. The surface accumulation is smallest where the leeward slope is largest, and the accumulation is a maximum downstream where the leeward slope is small. A negative correlation of -0.7 was found between leeward surface slope and accumulation rate. This shows that the accumulation regime depends on the downslope surface gradient (aspect northwest). The same relation was also found for the two other strain nets located in profile 1 (Fig. 1) and has been recognised in previous studies such as Black and Budd (1964), Gow and Rowland (1965) and Whillans (1975). The large variability, up to $100 \%$, in accumulation over the strain net is due to differences in removal and deposit efficiency of the surface snow layers related to the local surface slope, a process that will lower the positive relief feature and fill the hollows. Some of the variations could also be due to migration of longwave dunes as reported from measurements near Byrd Station (Whillans, 1978) and in eastern Kemp Land (Goodwin and others, 1994). During the summer, when measurements were taken, the small-scale relief (sastrugi and dunes) is $0-0.3 \mathrm{~m}$, equivalent to about $10 \mathrm{~kg} \mathrm{~m}^{-2} \mathrm{a}^{-1}$ of accumulation. The aspect-dependent accumulation pattern is thus the most important factor for the areal variation in mass balance in this part of Jutulstraumen. 


\section{Effect on firn-core stratigraphy}

Considerable interannual variability, up to $250 \%$, was found in annual accumulation from the firn-core stratigraphy (Table 2). The variability is due to the combined effect of year-to-year "climate" variations, flow of the ice stream (ice in the core did not accumulate at a single location) and the effect of drifts and sastrugi (micro-relief). The accumulation records from the cores have not been adjusted for the upstream accumulation gradient, since this is assumed to be negligible over the few $\mathrm{km}$ distance from which the snow originated. The effect of movement of the core site through geographical variations in surface mass balance, however, does need to be considered for cores A-D in the ice stream, where the ice movement rate is high $\left(200-400 \mathrm{~m} \mathrm{a}^{-1}\right)$, but not at core site $\mathrm{H}$ where the ice movement is only a few $\mathrm{m} \mathrm{a}^{-1}$. Figure 4 shows that large horizontal variations in surface mass balance of up to $500 \mathrm{~kg} \mathrm{~m}^{-2} \mathrm{a}^{-1}$ occur over a distance of less then $3 \mathrm{~km}$ parallel to the flow direction. The effect of the variations will most probably be preserved in the firn-core stratigraphy since microrelief features are preserved (Whillans, 1978; Petit and others, 1982). This demonstrates that a large part of the variability in annual accumulation rates at core sites $\mathrm{A}-\mathrm{D}$ could be due to the effect of moving the core-hole site through a geographically fixed variation in surface mass balance, and not climatic variations. The long time mean will therefore be a more reliable estimate of net accumulation.

\section{Variation of accumulation with major topography}

Generally, surface mass balance decreases with distance from the coast, varying from about $230 \mathrm{~kg} \mathrm{~m}^{-2} \mathrm{a}^{-1}$ in the coastal region to less then $160 \mathrm{~kg} \mathrm{~m}^{-2} \mathrm{a}^{-1}$ at the front of the plateau, $420 \mathrm{~km}$ inland and $2414 \mathrm{~m}$ a.s.l. This pattern seems to continue further into the plateau, and an accumulation of only $77 \mathrm{~kg} \mathrm{~m}^{-2} \mathrm{a}^{-1}$ was found by Isaksson and others (1996) at $75^{\circ} \mathrm{S}, 2^{\circ} \mathrm{E}$, a distance of $620 \mathrm{~km}$ from the coast at $2900 \mathrm{~m}$ a.s.l. This overall decreasing trend is expected since precipitation (accumulation) is a function of distance from moisture source, temperature and elevation (Fortuin and Oerlemans, 1990; Giovinetto and others, 1990).

Figure 2 also shows that the region between 270 and $300 \mathrm{~km}$ (elevation interval 900-1200 m a.s.1.) diverges from the general trend in having a relatively high accumulation. A similar phenomenon was found (900-1200 m a.s.l.) on the ice sheet further west for the period 1957-59 (Swithinbank, 1959). The accumulation pattern there was related to altitude effects and deposits of snow transported by katabatic winds. OnJutulstraumen a change in the nature of the topography occurs on moving from the relatively flat ice-shelf area to the steeper ice stream. The change in topography causes orographic uplift and adiabatic cooling of humid air, giving rise to a zone of increased precipitation. In the same interval, Jutulstraumen changes flow direction (Fig. 1) from north to northeast. This probably causes a decrease in katabatic wind speed since the katabatic winds will only partly follow the ice stream, resulting in deposits of drifting snow. The effect of the snow deposits on the accumulation rate in this area is demonstrated by the stake measurements along profile 1 . The relatively high accumulation between 900 and $1200 \mathrm{~m}$ elevation is thus a result of both increased precipitation due to orographic uplift and increased deposi- tion of transported snow due to divergence and decrease of katabatic wind speed.

A major accumulation deficit is found at core sites $\mathrm{E}$ and I (Fig. 2). Core site E is located in an area of small-scale (few $\mathrm{km}$ ) hills, and the surface microrelief is characterised by lanceolate sastrugi developed in wind-crusted snow (using Goodwin's (1990) classification). About $5 \mathrm{~km}$ to the west, blue ice could be seen on a large convexity. Relatively low accumulation on convex, as compared to concave, topography has been reported from various Antarctic studies (e.g. Schytt, 1958; Swithinbank, 1959; Gow and others, 1972; Whillans, 1975; Takahashi and others, 1994). Modelling results of winter air-flow patterns over the Antarctic ice sheet by Parish and Bromwich (1987) and Parish (1988) show that Jutulstraumen is located in a broad-scale confluence zone of katabatic winds. Strong southeast katabatic winds are thus expected during winter, resulting in correspondingly large transport and erosion potential along the ice stream. Wind speed is accelerated on convex topography because of the higher surface slope. The most plausible explanation for the low accumulation at core site $\mathrm{E}$ is erosion due to windscouring. Wind-scouring would also explain the ambiguous oxygen stratigraphy found in core $\mathrm{E}$ since it has been shown that wind-scouring has a large effect on the oxygen-isotope profile (Fisher and others, 1983).

Core site I $(700 \mathrm{~m}$ a.s.l.) is not in the drainage basin of Jutulstraumen but about $30 \mathrm{~km}$ east and $20 \mathrm{~km}$ south of the grounding line in a region where katabatic winds diverge horizontally on the north aspect slope. This is an area of mixed snow and blue-ice fields. The north-sloping area is favourably exposed to incoming solar radiation, and low accumulation rates result from the strong katabatic winds (Winther and others, 1996). A gradual decrease in the blueice extension can be seen on Norsk Polarinstitutt satellite maps (sheet No. H5S, Jutulgryta) on moving towards core site I nearer the mountains H.U. Sverdrupfjella (Fig. 1). The low accumulation rate at site I could therefore be a result of one or more of wind-scouring, low precipitation or higher sublimation rates.

\section{CONCLUSIONS}

Generally, the surface mass balance decreases with distance from the coast and increased elevation: from about $230 \mathrm{~kg}$ $\mathrm{m}^{-2} \mathrm{a}^{-1}$ in the coastal region to less than $160 \mathrm{~kg} \mathrm{~m}^{-2} \mathrm{a}^{-1}$ at the front of the plateau at a distance of $420 \mathrm{~km}$ from the coast and $2414 \mathrm{~m}$ a.s.l. However, divergence from this general trend is found in the elevation interval $900-1200 \mathrm{~m}$ a.s.l. where relatively high accumulation of up to $780 \mathrm{~kg} \mathrm{~m}^{-2} \mathrm{a}^{-1}$ occurs. A major accumulation deficit is found at core sites $\mathrm{E}$ and I.

Locally we found large variations of up to $100 \%$ in accumulation rate over distances of less then $3 \mathrm{~km}$. The accumulation distribution was found to be dependent upon local surface topography and more specifically on the downslope surface gradient or aspect with respect to the katabatic wind direction. Some of the variations could also be due to migration of longwave dunes (Whillans, 1978; Goodwin and others, 1994), but this seems to play a minor role. The studies demonstrate the importance of the local topography for the interpretation of firn-core stratigraphy. The largest part of the interannual variability in accumulation rates found in the cores from the fast-flowing Jutulstraumen could be due 
to the movement of the core site through a horizontal, geographically fixed variation in surface mass balance. The results are important for the interpretation of temporal variations of existing firn cores and for the selection of new sites for core drilling. The long time mean should be used for the most reliable estimate of the net accumulation.

\section{ACKNOWLEDGEMENTS}

We are grateful to Norsk Polarinstitutt, Oslo, for logistical help and for their excellent organisation of the expeditions, NARE 1992-93, 1993-94 and 1996-97. We are also grateful to our colleagues at the Geophysical Department, University of Copenhagen, and at the Laboratoire de Glaciologie et Géophysique de l'Environnement, Grenoble, who have been extremely helpful with the core analysis. We would like to thank our field assistants, T. Laumann, T. Tonning and C. Rolstad, and we are grateful to H. Elvehøy, C. E. Bøggild and K. Sand for drilling core I. The project was financed by the Norwegian Research Council. This is publication No. 146 of NARE (1996-97).

\section{REFERENGES}

Aristarain, A. J., J. F. Pinglot and M. Pourchet. 1987. Accumulation and temperature measurements on the James Ross Island ice cap, Antarctic Peninsula, Antarctica. 7. Glaciol., 33(115), 357-362.

Black, H. P. and W. Budd. 1964. Accumulation in the region of Wilkes, Wilkes Land, Antarctica. 7. Glaciol., 5(37), 3-15.

Clausen, H. B., W. Dansgaard, J. O. Nielsen and J.W. Clough. 1979. Surface accumulation on Ross Ice Shelf. Antarct. 7. U.S., 14(5), 68-72.

Decleir, H. and T. van Autenboer. 1982. Gravity and magnetic anomalies across Jutulstraumen, a major geologic feature in western Dronning Maud Land. In Craddock, C., ed. Antarctic geoscience: Third Symposium on Antarctic Geology and Geophysics, Madison, Wisconsin, U.S.A., August 22-27 1977. Madison, WI, University of Wisconsin Press, 941-948.

Delmas, R. and M. Pourchet. 1977. Utilisation de filtres échangeurs d'ions pour l'étude de l'activité $\beta$ globale d'un carottage glaciologique. International Association of Hydrological Sciences Publication 118 (Symposium at Grenoble 1975 - Isotopes and Impurities in Snow and Ice), 159-163.

Eiken, T., J. O. Hagen and K. Melvold. 1997. Kinematic GPS survey of geometry changes on Svalbard glaciers. Ann. Glaciol., 24, 157-163.

Fisher, D. A., R. M. Koerner, W. S. B. Paterson, W. Dansgaard, N. Gundestrup and N. Reeh. 1983. Effect of wind scouring on climatic records from ice-core oxygen-isotope profiles. Nature, 301 (5897), 205-209.

Fortuin, J. P. F. and J. Oerlemans. 1990. Parameterization of the annual surface temperature and mass balance of Antarctica. Ann. Glaciol., 14, 78-84.

Giovinetto, M. B. 1964. The drainage system of Antarctica: accumulation. In Mellor, M., ed. Antarctic snow and ice studies. Washington, DC, American Geophysical Union, 127-155. (Antarctic Research Series 2.)

Giovinetto, M. B., N. M. Waters and C. R. Bentley. 1990. Dependence of Antarctic surface mass balance on temperature, elevation, and distance to open ocean. 7. Geophys. Res., 95(D4), 3517-3531.

Gjessing,Y.T. 1972. Mass transport of Jutulstraumen ice stream in Dronning Maud Land. Nor. Polarinst. Arbok 1970, 227-232.

Goodwin, I. D. 1990. Snow accumulation and surface topography in the katabatic zone of eastern Wilkes Land, Antarctica. Antarct. Sci., 2(3), 235-242.

Goodwin, I. D., M. Higham, I. Allison and R. Jiawen. 1994. Accumulation variation in eastern Kemp Land, Antarctica. Ann. Glaciol., 20, 202-206. Gow, A. J. and R. Rowland. 1965. On the relationship of snow accumulation to surface topography at "Byrd Station", Antarctica. 7. Glaciol., 5(42), 843-847.

Gow, A. J., F. de Blander, G. Crozaz and E. Picciotto. 1972. Snow accumulation at "Byrd" station, Antarctica. f. Glaciol., 11 (61), 59-64.

Hagen, J. O. and K. Melvold. 1997. Mass balance and dynamics on Jutulstraumen ice stream, NARE 1992/93. In Orheim, O., ed. Report of the Norwegian Antarctic Research Expedition (NARE) 1992/93. Oslo, Norsk Polarinstitutt. (Meddelelser 125.)

Høydal, Ø. A. 1996. A force-balance study of ice flow and basal conditions of Jutulstraumen, Antarctica. f. Glaciol., 42(142), 413-425.

Isaksson, E. and W. Karlén. 1994. Spatial and temporal patterns in snow accumulation, western Dronning Maud Land, Antarctica. 7. Glaciol., 40(135), 399-409.

Isaksson, E., W. Karlén, N. Gundestrup, P. Mayewski, S. Whitlow and M. Twickler. 1996. A century of accumulation and temperature changes in Dronning Maud Land, Antarctica. J. Geophys. Res., 101 (D3), 7085-7094.

Lunde, T. 1961. On the snow accumulation in Dronning Maud Land. Nor. Polarinst. Skr. 123.

Melvold, K., J. O. Hagen, T. Laumann and T. Tonning. 1996. Mass balance and dynamics on Jutulstraumen ice stream NARE 1993/94. In Winther, J. G., ed. Report of the Norwegian Antarctic Research Expedition (NARE) 1993/ 94. Oslo, Norsk Polarinstitutt, 19-24. (Meddelelser 140.)

Orheim, O. and 6 others. 1986. Oxygen isotopes and accumulation rate at Riiser-Larsenisen, Antarctica. Nor. Polarinst. Skr. 187, 33-47.

Parish, T. R. 1988. Surface winds over the Antarctic continent: a review. Rev. Geophys., 26(1), 169-180.

Parish, T. R. and D. H. Bromwich. 1987. The surface windfield over the Antarctic ice sheets. Nature, 328(6125), 51-54.

Peel, D. A. and H. B. Clausen. 1982. Oxygen-isotope and total beta-radioactivity measurements on $10 \mathrm{~m}$ ice cores from the Antarctic Peninsula. 7. Glaciol., 28(98), 43-55.

Picciotto, E., G. Crozaz andW. de Breuck. 1971. Accumulation on the South Pole-Queen Maud Land traverse, 1964-1968. In Crary, A. P., ed. Antarctic snow and ice studies II. Washington, DC, American Geophysical Union, 257-315. (Antarctic Research Series 16.)

Pinglot, J. F. and M. Pourchet. 1979. Low-level beta counting with an automatic sample changer. Nucl. Instrum. Methods, 166(3), 483-490.

Pinglot, J. F. and M. Pourchet. 1981. Gamma-ray bore-hole logging for determining radioactive fallout layers in snow. In Methods of low-level counting and spectrometry. Vienna, International Atomic Energy Agency, 161-172. (SM 252/55.).

Schytt, V. 1958. Snow studies inland. Norwegian-British-Swedish Antarctic Expedition, 1949-52. Sci. Results IV, Glaciology II, B, 65-112.

Swithinbank, C. 1959. The regime of the ice sheet of western Dronning Maud Land as shown by stake measurements. Norwegian-British-Swedish Antartic Expedition, 1949-52. Sci. Results III, Glaciology I, E, 121-144.

Swithinbank, C. 1988. Antarctica. U.S. Geol. Surv. Prof. Pap. 1386-B, Bl-B138.

Takahashi, S., Y. Ageta, Y. Fujii and O. Watanabe. 1994. Surface mass balance in east Dronning Maud Land, Antarctica, observed by Japanese Antarctic Research Expeditions. Ann. Glaciol., 20, 242-248.

Van den Broeke, M. R. and R. Bintanja. 1995. The interaction of katabatic winds and the formation of blue-ice areas in East Antarctica. F. Glaciol., 41 (138), 395-407.

Whillans, I. M. 1975. Effect of inversion winds on topographic detail and mass balance on inland ice sheets. 7. Glaciol., 14(70), 85-90.

Whillans, I. M. 1978. Surface mass-balance variability near "Byrd" station, Antarctica, and its importance to ice core stratigraphy. 7. Glaciol., 20(83), 301-310.

Winther, J.-G., H. Elvehøy, C. E. Bøggild, K. Sand and G. Liston. 1996. Melting, runoff and the formation of frozen lakes in a mixed snow and blue-ice field in Dronning Maud Land, Antarctica. f. Glaciol., 42(141), 271-278. 